\section{For medicinal purposes}

\section{Alan Glynn}

Plagues and Politics: The Story of the United States Public Health Service. By Fitzhugh Mullan. Basic Books, New York: 1989. Pp. 223. \$26.95.

The United States Public Health Service (PHS) is the direct and legitimate descendant of the United States Marine Hospital Service (MHS), which was born, by Act of Congress, in 1798. What then is this centennial volume, numerate readers may ask? The centenary involved is that of the 'Commissioned Corps', established (or at least formalized) by another Act in 1889 , which formed an élite of medical men until the pressure of the Second World War forced the entry of non-medical scientists, engineers and women.

Mullan deals with the whole of the PHS's activities, but it is the Commissioned Corps who are the good guys. 'Plagues' are the leading baddies, though 'Politics' are not always far behind. In 1870 a reforming Act recommended central control of the MHS by a supervising surgeon in Washington, but stipulated that he must be drawn from civil life. This blocked the appointment of the man who had contributed most to the report on which the Act was based, John Shaw Billings, arguably the best Surgeon General the PHS never had. The reason for this restriction is not made clear. Antimilitarism is less likely than simple politi-

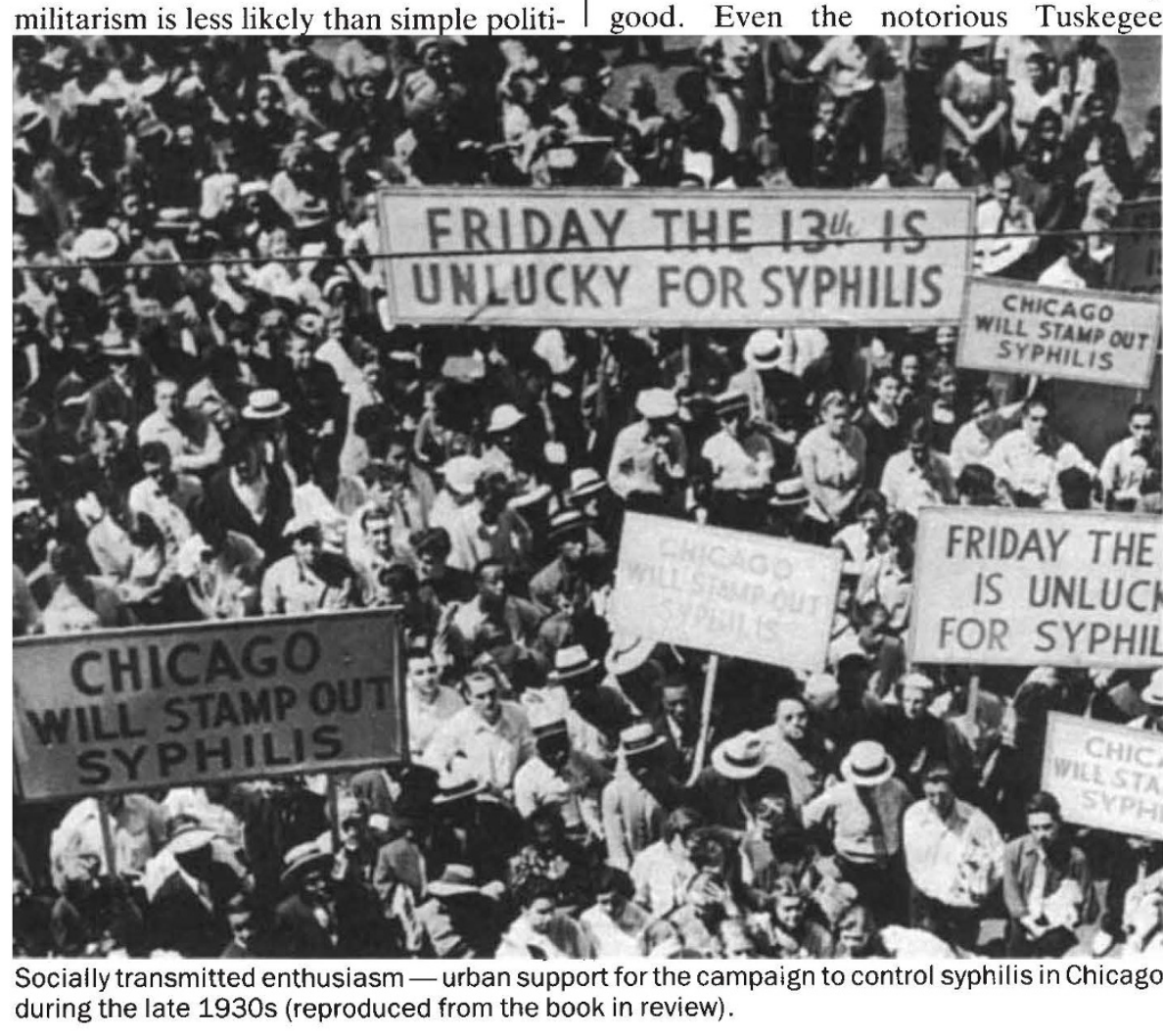

Socially transmitted enthusiasm - urban support for the campaign to control syphilis in Chicago during the late 1930s (reproduced from the book in review). cal favouritism. Billings's successful rival, John Woodworth, had been the senior medical officer under Sherman.

In an age when there was blatant outside interference in civil-service appointments, Woodworth copied the army model for appointments and later introduced stiff professional examinations for entry to the MHS. The title Supervising Surgeon changed imperceptibly to Supervising Surgeon General, and finally to Surgeon General. Meanwhile, Billings was working in the office of the Surgeon General (of the army), and was building up what became the greatest medical library in the world and introducing a new were transferred to the PHS in 1956.

These early rivalries set the tone for the next century. Successive Surgeons General had to contend with civil-service better. By restricting entry to the Commissioned Corps to physicians, they made it difficult to recruit scientists of quality, so handicapping the work and limiting its scope. Paradoxically, as Mullan points out, they also fought numerous proposals to develop aspects of public health not because they were undesirable but because they might have produced competing agencies.

Plagues and Politics is not just a picture book (although the pictures are very good). It gives a very readable account of the battles the PHS has fought, on the whole successfully, against disease, the US treasury and public health reformers in and outside government. Against disease the PHS's record is extraordinarily good. Even the notorious Tuskegee idea, the Index Medicus. Ironically, both jealousies because pay in the PHS was project, if judged by the ethics of its time, was at least well meant. Goldberger's demonstration of the nutritional basis of pellagra and Stiles's work on hookworm are just two examples of many successful investigations and campaigns.

In a different category comes Lumsden's pioneering work on rural sanitation. Unfortunately, his views on federal help for states differed from those of Surgeon General Cummings, and he was eventually 'exiled' to New Orleans. Indeed, one of the alleged merits of the Commissioned Corps was that its members could be posted anywhere. This also meant overseas, and the PHS's worldwide experience of disease problems must have influenced Surgeon General Parran, who played a large part in the creation of the World Health Organization. Although Mullan makes several references to the Centers for Disease Control, the epidemiological nerve centre which grew out of the Program for Malaria Control in War Areas, he does not adequately convey its full importance.

Early political battles were mostly about money or federal-state relations. The later struggles for organizational power are more difficult for an outsider to understand, because they involve many interests, to say nothing of the acronyms for numerous and sometimes ephemeral agencies. Not infrequently, politics and disease were both involved. When Kinoun was sent to deal with the first outbreak of plague in the United States he was vilified by the Governor of California and other local interests, whose reactions were similar to those of some local authorities in England when cholera arrived in 1832. After the Second World War the changed views of government and public on public health inevitably brought changes to the traditional PHS. After some anxious moments in the 1970s, when only an acting Surgeon General was appointed and all authority was vested in the Assistant Secretary for Health, the PHS is now reasonably settled as part of the Department of Health Education and Welfare. In his campaign against AIDS, the former Surgeon General, C. Everett Koop, has upheld the PHS's tradition of attacking disease problems where it thinks necessary, whether or not governments are keen to follow.

Perhaps Plagues and Politics should be looked on as a forerunner to some future monumental work on the PHS that will answer all the unanswered questions. But such a book is unlikely to be as readable. Perhaps, too, someone will write a similar history of public health and government in Britain, comparing the Surgeon General with the Chief Medical Officer. It would be fascinating and instructive.

Alan Glynn, Central Public Health Laboratory Colindale, London NW9 5HT, UK, retired last year as director of the laboratory. 